\title{
Level of Ability to Use Weight Training Tools for Students of Department of Sports Sciences Universitas Negeri Medan
}

\author{
Zulaini $^{1}$, Marsal Risfandi ${ }^{2}$ and Agus Salim Samosir ${ }^{3}$ \\ \{zulaini@unimed.ac.id ${ }^{1}$ \} \\ Department of Sport Science, State University of Medan, North Sumatera, Indonesia ${ }^{123}$
}

\begin{abstract}
The purpose of this study was to determine the ability to use weight training tools in the form of shoulder presses, bench presses, leg presses, chest presses, and pull downs for students of sports study programs. This research is a qualitative descriptive study using survey methods. The population was fifth semester sports students who had graduated in taking courses in anatomy, physiology, kinesiology, and biomechanics. Based on this, a sample of nineteen people was obtained. The results showed that the ability of students in the use of weight training equipment with the type of shoulder press training, bench press, leg press training, chest press exercises, pull down exercises have an average score of two with category is "Good".
\end{abstract}

Keywords: Ability, weight training tools.

\section{Introduction}

The Sport Science Study Program organizes academic education with the aim of producing graduates in the field of sports with qualifications nationalist, honest, tough, responsible and responsive education demands for sports development. The graduates of the Sport Science Study Program have competency as a skilled worker in the management of Sports Health and Fitness, Sports Recreation, Community Sports, Disabled Sports (adaptive sports),Sports Achievement, and Amateur Sports.

Sport is a necessity for everyone. The need for availability fitness center is increasingly mushrooming especially in urban areas. This is also comparable to the increasing need for personal trainers. Along with the level of personal need trainers who are increasing in higher education must also consider competencies support graduates so that they can have high competitiveness in the world of work. Strengthening this competence is carried out before students enter the world of internship in the company. So that students are ready when entering the sports industry.

One of the demands of being a Personal Trainer is having the good and right ability in using fitness equipment. Basically there are two types of equipment you will find in a fitness center, among others, is Lifting Charges and Machines. Weight lifting serves to train muscles while the machine functions to train cardio.

Before having the ability to use these fitness equipment then students must be provided with Sports Biomechanics. Biomechanics is science discuss the mechanical aspects of human body movements. Biomechanics is combination of mechanical science, anthropometry and the 
basis of medical science. On Biomechanics approaches there are several definitions of biomechanics that we can use. According to Hatze (1974), Biomechanics is the study of the structure and function of biological systems with using knowledge and mechanical methods.

Meanwhile, according to James (1985), Biomechanics is the study of style forces that occur in biological structures and effects produced by certain forces. So can be concluded, Biomechanics is a science that uses the laws of physics and the concept of engineering to study the movements experienced by several body segments and the forces that occur in this part of the body during normal activity.

The purpose of studying biomechanics in the application of sports science is: 1) Knowing the basic scientific concepts that are applied in the form of human motion; 2) Understand form / model of basic motion in sports so that it can develop it with good; 3) Able to understand the development of basic movements; 4) Able to apply a form which is in accordance with a person's physical characteristics in exercising, properly and correctly. As a student of the Sport Science Study Program, must have knowledge regarding techniques, types of exercises, the benefits of tools, and how to do fitness equipment properly.

The use of fitness equipment such as improper load tools can result injury to muscles, bones, nerves, respiratory system is disrupted, and results of training that are not appropriate with training objectives. In order for the exercise program to run according to purpose, training must be programmed according to the rules of practice that are correct and in accordance with the concept, measure, principle practice, and so on. Besides that the way to do weight training is wrong to affect the results of training.

Based on the foregoing, it is necessary to examine how the motion technique of sports science students in using weight training tools.

\section{Methods}

\subsection{Subjects and procedures}

Number of population in this study were students of sport science program study numbering 231people. The sampling technique in this study uses techniques purposive sampling is sampling based on a particular consideration made by the researcher himself based on research needs without eliminating the characteristics and the characteristics of the population that have been known before (Arikunto, 2010). The sample criteria these are: 1) Students who have graduated in the biomechanics of sports courses; 2)5th semester students; 3) Willing to be a sample when collecting data. Based on these criteria then obtained the number of samples in the study amounted to 17 people. According to Nursalam (2013) the research design is very important in research, it allows maximum control of several factors that can affect the accuracy of a result

At this stage, the researcher must consider several decisions regarding with a method that will be used to answer research questions and must be carefully plan data collection. The researcher must be aware that each method is used has an impact on the quality, unity and interpretation of an outcome. Therefore, researchers must be able to evaluate the decision to determine how much the truth that will be presented in the results of the study (Nursalam, 2013). The research design used is descriptive research through this method researchers want to compile a manual procedure for using fitness equipment that will used by students of the Sport Science Study Program through the course of Sports Biomechanics. 


\subsection{Statistical analysis}

Data collection is done by distributing an observation sheet about how to do fitness equipment correctly. Data is obtained from primary data, namely data obtained directly from object of research by researchers, so that answers to questions are provided (Riwidikdo, 2009). During the data collection process, researchers focus on providing subject, pay attention to the principles of validity and reliability, and solve problems that occur so that the data is collected according to the plan that has been set. Data analysis techniques in this study used descriptive analysis techniques. On when observing the technical movements carried out by the sample, the researcher is assisted by experts in analyzing data. These experts participate directly with researchers at the time of data collection so that data becomes valid. Data were analyzed then added and percentage. In this study, to facilitate the description of research results

Four criteria were made which included Very Good (SB) with a value of 4, Good (B) with a value of 3 , Not Good (TB) with a value of 2, and Very Bad (STB) with a value of 1 . Basic determination this category is to maintain the level of consistency in this study, as well as make it easier in determining the interval, so that the analysis becomes easier. The data obtained is then analyzed and expressed in the form of percentages, searched with the following formula:

$$
\mathrm{P}=\stackrel{\mathrm{F}}{\mathrm{N}} \times 100 \%
$$

Before being disseminated, the data obtained were analyzed using statistics Descriptions are then converted into qualitative data to help researchers in draw conclusions about the motion technique of using weight training equipment.

\section{Result and discussion}

Based on the results of the study, it was obtained data about the ability of students in using weight training tools can be seen in the table below:.

Tables 1.. Distribution of Frequency of Student Ability in Using Weight Training Tools.

\begin{tabular}{|c|c|c|c|c|c|c|c|c|c|}
\hline \multirow{3}{*}{$\begin{array}{l}\mathbf{N} \\
\mathbf{0}\end{array}$} & \multirow{3}{*}{ Category } & \multicolumn{8}{|c|}{ Type of Exercise } \\
\hline & & \multicolumn{2}{|c|}{ Shoulder Press } & \multicolumn{2}{|c|}{ Leg Press } & \multicolumn{2}{|c|}{ Bench Press } & \multicolumn{2}{|c|}{ Pull Down } \\
\hline & & Amount & $\%$ & Amount & $\%$ & Amount & $\%$ & Amount & $\%$ \\
\hline 1 & $\begin{array}{l}\text { Very } \\
\text { Good }\end{array}$ & - & - & - & - & - & - & - & - \\
\hline 2 & Good & 15 & 88 & 4 & 23 & 15 & 88 & 12 & 70 \\
\hline 3 & Bad & 2 & 12 & 13 & 77 & 2 & 12 & 5 & 30 \\
\hline 4 & Very Bad & - & - & - & - & - & - & - & - \\
\hline & Sum & 17 & 100 & 17 & 100 & 17 & 100 & 17 & 100 \\
\hline
\end{tabular}


The data above shows that the ability of students using shoulder press tool by $88 \%$ is in good category, ability using Leg press tools by $77 \%$ is in the bad category, the ability of students using the bench press tools by $88 \%$ is in the good category and the ability of students using the pull down tools by $70 \%$ is in the good category.

Tables 2. Data Assessment of Motion of Techniques Judging from the Type of Exercise.

\begin{tabular}{lll}
\hline Exercise & Score & Category \\
\hline Shoulder Press & 2.88 & Good \\
Leg Press & 2.23 & Bad \\
Bench Press & 2.88 & Good \\
Pull Down & 2.76 & Good \\
Average & $\mathbf{2 . 6 8}$ & Good \\
\hline
\end{tabular}

Table 2 above shows the average value of the motion assessment seen from the overall type of exercise is 2.68 with a good category.

The average value obtained from the results of this study is the ability of students in using weight training tools is in good category. According to Notoatmodjo (2003) knowledge is the result of "knowing" and this happens after people do it sensing of a particular object. Knowledge is also obtained from education, self-experience and experience of others, mass media and the environment. The knowledge a person has will determine how action takes place that person. According to Sunaryo (2004) states that behavior is realized by knowledge will be more lasting than behavior that is not realized by knowledge. Students of the Sport Science Study Program who were sampled in this study have follow and pass courses in anatomy, physiology, kinesiology and biomechanics. Thus they can use weight training tools properly.

Based on the results obtained, shows the use of the Leg Press training tool is an average score. The average obtained is 2.23 with a bad category. This is caused by the results of observations made were students who were sampled pushing the pedals until both legs are straight, not straight forward, and do not regulate the breath push. The wrong pushing the pedals can be seen on picture below. The use of overloading loads will stimulate the adjustment of physiology in the body that encourages increased muscle work. According kravitz (2001: 20) to increase the training load by increasing the intensity of the duration or frequency of a level of training that is commonly done. If someone uses this leg press tool with excessive load it will cause injury. It was stated in more detail by Harsono (1988: 187195) that the principles of weight training must be fulfilled, so that the training program guarantees added power step by step, and reduces the risk of injury to muscle fibers.

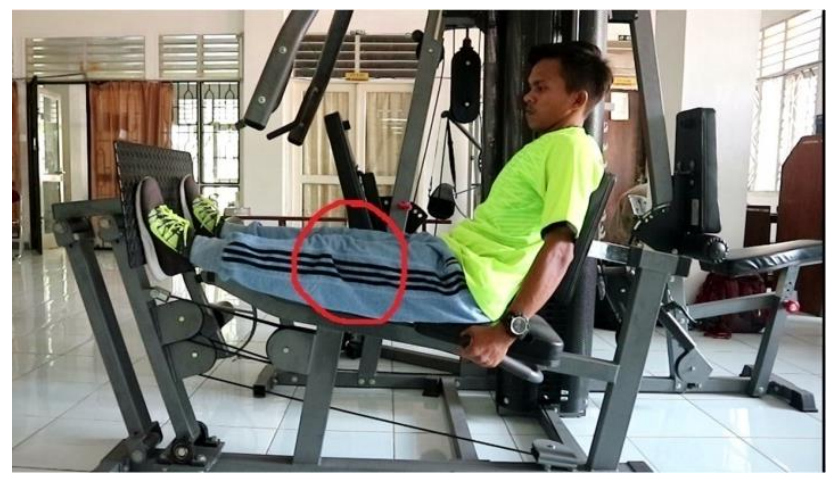


Figure1. Red Circle Shows wrong in straight leg position when pushing the pedal

Leg press training is a weight training using a leg press machine, this exercise aims to increase the strength of the leg muscles (groves, 1997). By giving weight training using leg press machine, there is an increase in leg muscle strength with hypertrophy in the muscles, an increase in muscle tone and an increase in recruitment in the motor unit which will affect the contraction in the muscles.

In addition, mistakes made at the Bench Press training position, one of which is the position of the leg that is not bent when lying down. For more details can be seen on Figure 2.

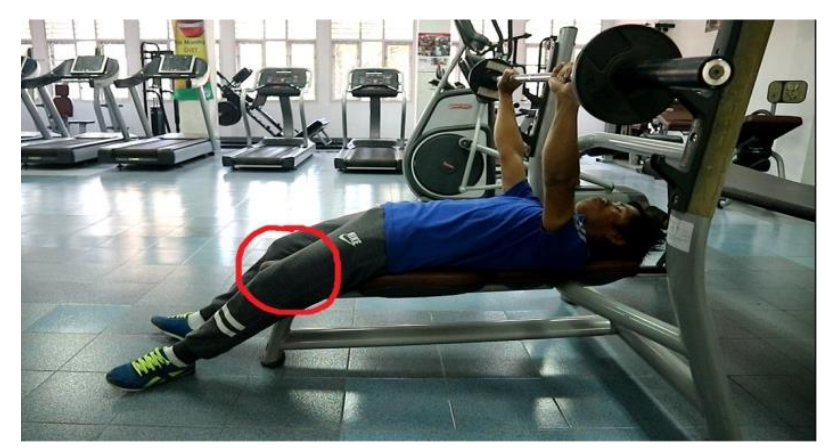

Figure 2. Red Circle Shows Error of Leg Position Not Bended When Bench Press Training Position.

In addition to the legs, the body part that is often prone to injury when doing bench press is the waist. This is due to when lifting the load up to the position of the waist in a swaying state. This will cause serious injury to the joint. According to Ade Rai (2008: 49) is a training movement similar to the bench press or incline press, only done on the decline bench which has a certain slope (around 20-30 degrees) down. This exercise concentrates the pressure on the lower chest muscles so that the chest muscles can become thicker and look full. According to Ade Rai (2008: 48) this exercise is the best exercise for chest muscles. Hold the handle slightly wider than the shoulder width. Don't be too wide because it will overload the joints too heavy. Lower the load slowly so that it touches the chest. When pushing the load up, make a slight angle, do not push it straight up, this causes the deltoid muscles to play a lot.

The importance of a person's ability to use weight training tools must be in line with his knowledge of basic principles in fitness training. According to Djoko Pekik (2000: 19) to achieve the goal of optimal exercise or fitness, it is necessary to know the basic principles in fitness training which have a very important role in physiological and psychological aspects.

To further enhance the ability of students in sports science study programs, it is then recommended to create a procedure manual on the instructions for using good and correct weight training tools Italics can be used for emphasis and bold typeset should be avoided. 


\section{Conclusion}

The average value of students' ability to use weight training tools is amounting to 2.68 and in good category.

Acknowledgements. The research was supported by DIPA of UNIMED. 


\section{References}

[1] Ade Rai. : Fitness and Healthy Body Building Healthy Lifestyle. Tabloid Bola, Jakarta: (2008)

[2] Arikunto, S.: Research Procedure A Practical Approach. Rineka Cipta, Jakarta (2010)

[3] Djoko Pekik Irianto.: Fitness exercise guide (effective and safe). Lukman Offset, Yogyakarta (2000)

[4] Groves, Barney R.: Jakarta Load Training: PT Rajagrafindo Persada (1997)

[5] Hatze, H.: The meaning of the term biomechanics, Journal of Biomechanics 7, p189-190, (1974)

[6] Harsono.: Coaching and Psychological Aspects in Coaching. CV. Kusuma Pond, Jakarta (1988)

[7] James. G. Hay.: The Biomechanic of Sport Techniques, Prentice Hall Englewood Cliffs. New Jrsey (1985)

[8] Kravitz, Len.: Total Fit. Raja Grafindo Persada, Jakarta (2001)

[9] Notoatmodjo Soekidjo.: Public Health Sciences. Rineka Cipta, Jakarta (2003)

[10] Nursalam.: Research Methodology: Practical Approach (edition 3). Salemba Medika, Jakarta (2013)

[11] Riwidikdo, Handoko.: Health Statistics: Easy learning of data analysis techniques in Health Research (SPSS Software Application Plus). Partner Cendikia Press, Yogyakarta (2009)

[12] Sunaryo.: Psychology for Nurses. EGC, Jakarta (2004) 